\title{
Muğla Mermerinin Esnek Üstyapılı Yol Kaplamalarında Kullanımının Performansa Etkisinin Değerlendirilmesi, Suya Bağlı Bozulmalara Karşı Direncinin İncelenmesi
}

\author{
Evaluation of the Effect on Performance of Muğla Marble Usage in Flexible Pavements, \\ Investigation of the Resistance of Water Induced Damages
}

\author{
Mustafa ÖZKAN ${ }^{1, a}$, İsmail Çağrı GÖRKEM*2,b \\ ${ }^{I}$ Muğla Sitkı Koçman Üniversitesi, Fen Bilimleri Enstitüsü, İnşaat Mühendisliği Anabilim Dalı, 48000, Muğla \\ ${ }^{2}$ Muğla Sitkr Koçman Üniversitesi, Mühendislik Fakültesi, İşaat Mühendisliği Bölümü, 48000, Muğla
}

• Geliş tarihi / Received: 09.08.2019 • • Düzeltilerek geliş tarihi / Received in revised form: 28.01.2020 • Kabul tarihi / Accepted: 03.02.2020

\begin{abstract}
$\ddot{O} z$
Yeni ürünler elde etmek veya atıkların katkı maddesi olarak kullanılması amacıyla günümüzde, atık malzemelerin esnek üstyapılı yol kaplamalarında kullanımı ve değerlendirilmesi konusunda yoğun çalışmalar yapılmaktadır. $\mathrm{Bu}$ malzemelerin tekrardan kullanımı ile geri dönüşümü düşüncesi, sınırlı olan doğal kaynakların kullanımını azaltmakta, çevrenin tahrip edilmesini önlemekte, üretimde verimliliği arttırmakta ve atık depolanması sonucu oluşacak çevresel sorunları en aza indirgemektedir. Bu çalışmada mermer atıklarının, esnek üstyapılı yol kaplamalarında değerlendirilmesi konusuna değinilmiştir. Numuneler üzerinde standart agrega ve geleneksel bitüm deneyleri ile karışımın performans özelliklerinin belirlenmesi amacıyla Marshall stabilite ve akma deneyleri yapılmıştır. Kalsit bazlı mermer atı̆ğ ile hazırlanan bitümlü karışım örneklerinin suya bağlı bozulmalara karşı direncin tespiti amacıyla numuneler üzerine Modifiye Lottman deneyi (AASHTO T283) uygulanmıştır. Elde edilen sonuçlar, Karayolu Teknik Şartnamesi'ne (KTŞ) göre değerlendirilmiş̧ir. Buna göre, kalsit bazlı mermer atı̆̆ agregaların fiziksel özelliklerinin ve bitümlü karışımdaki stabilite ve akma değerlerinin şartname limitleri içerisinde olduğu görülmüştür. Sönmüş kireç katkısı ile hazırlanan bitümlü karışımların suya bağlı bozulmalara karşı direnci artırdığı tespit edilmiştir. Kalsit bazlı mermer atığının orta ve düşük hacimli yollarda kalker agregasına alternatif olarak kullanılabileceği düşünülmektedir.
\end{abstract}

Anahtar kelimeler: Bitüm, Esnek Üstyapılar, Kalsit Bazlı Mermer Atığı, Sönmüş Kireç, Suya Bağlı Bozulmalar

\begin{abstract}
In order to obtain new products or to use wastes as additive materials, intensive studies are performed on the usage and evaluation of waste materials in flexible pavement. The idea of reuse these materials with recycling reduces the use of limited sources of nature, prevents the destruction of the environment, increases efficiency in production, and minimizes the environmental problems that may occur as a result of waste storage. In this study, the evaluation of marble wastes usage in flexible pavement has been mentioned. Traditional bitumen and aggregate tests and in order to determine the performance characteristics of the bituminous mixture Marshall stability and flow tests have been performed. The modified Lottman test (AASHTO T283) has been applied on the specimens to determine the resistance on water-induced damages of the bituminous mixture specimens prepared with calcite based marble waste. The results that obtained have been compared with the Technical Specification of Highway (KTSS). According to obtained, the physical properties of calcite-based marble waste aggregates as well as the stability and flow values of bituminous mixture have been found to be within the specification limits. It has been determined that the bituminous mixtures prepared with the hydrated lime additive increase the resistance on water-induced damages. Calcite-based marble waste aggregate is thought to be used as an alternative to limestone aggregate on medium and low volume traffic roads
\end{abstract}

Keywords: Bitumen, Flexible Pavement, Calcite Based Marble Waste, Hydrated Lime, Water Induced Damage

\footnotetext{
*b İsmail Çağrı GÖRKEM; cagrigorkem@mu.edu.tr, Tel: (0252) 211 55 78, orcid.org/0000-0001-9427-2637

${ }^{\mathrm{a}}$ orcid.org/ 0000-0002-2590-9689
} 


\section{Giriş}

Artan ticari faaliyetler ve bunlara bağlı olarak gelişen ulaştırma sektörü nedeniyle hali hazırdaki karayollarına etki eden dingil yük ve sayıları her geçen gün artmaktadır. Ticari faaliyetlerdeki bu artış ile birlikte yeni yollara olan gereksinim ortaya çıkmakta ve böylelikle günden güne yeni karayolu ağları inşa edilmektedir.

Dingil yüklerinin artması ve iklim koşullarındaki değişiklikler gibi nedenlerle mevcut yolların performanslarında düşüşler ve buna bağlı olarak hizmet ömründe ise azalmalar görülmekte; bu durum ise esnek üstyapılı yol kaplamalarında karşılaşılan farklı deformasyon çeşitlerinin oluşumunu tetiklemektedir. Esnek üstyapılı yol kaplamalarındaki deformasyonların bir sonucu olarak, bakım ve onarım için gereken maliyet artmaktadır. Yıllardır esnek üstyapılı yol kaplamaları üzerinde deformasyon etkilerinin azaltılması amacıyla birçok çalışma yapılmaktadır. Bunlardan bazıları bitümlü malzemenin modifikasyonuna yönelik olmakla beraber, diğerleri ise karışıma uygulanan iyileştirmeleri kapsamaktadır. Doğal kaynakların sınırlı olması ve artan çevre bilinci nedeniyle araştırmacılar günümüzde yol yapım tekniklerinde kullanılan malzemelere alternatif olabilecek kaynaklar üzerine çalışmalarını sürdürmektedirler.

Yol yapımında bitümlü malzemeler ile çimento ve kırma taş agregalar kullanılmaktadır. $\mathrm{Bu}$ malzemelerin belirtildiği üzere doğada sınırlı olmaları sebebiyle geri kazanılmış malzemelerin kullanımı dikkate alınması gereken bir konu haline gelmiştir. $\mathrm{Bu}$ açıdan bakıldığında, servis ömrü süresince yaşlanan bağlayıcılardan elde edilen okside olarak sertleşmiş bitüm malzemesinin kullanımı yeni çalışmalar için önem kazanmaktadır. Yol yapımında, alternatif kaynaklardan biri de atık agregaların bitümlü karışımlarda kullanılmasıdır (Karaşahin ve Terzi, 2007). Atık agregaların yol yapımındaki bu tekrar kullanımları, bu atıkların bertaraf edilmesi ve kirlilik problemine kısmen bir çözüm sunmaktadır (Aravind ve Das, 2004). Attk malzemeler, uygun görülen atı depolama sahalarında biriktirilmektedir. Çöp alanlarına dökülen atık maddeler, arazinin topografyasinı ve bu habitatlardaki canlıların yaşamlarını değiştirerek çevreye ciddi zararlar vermektedir (Akbulut ve Gürer, 2003).

Taş ocaklarında agrega üretimi için gereken yüksek enerji, üretim maliyetlerini arttırmaktadır. $\mathrm{Bu}$ maliyetlerin düşürülmesi amacıyla, alternatif agrega ürünlerinin kullanımlarına yönelik değerlendirmeler yapılmaktadır. Alternatif kaynaklardan biri de mermer üretim ocak ve tesislerinde kırım sırasında ortaya çıkan ve büyük bloklardan kopan agrega parçalarıdır. $\mathrm{Bu}$ atık mermer agregalarının uygun gradasyon ile kullanımının esnek üstyapılı yol kaplamalarında inşaat maliyetini azaltacağ 1 düşünülmektedir (Akbulut ve Gürer, 2006).

Esnek üstyapılı yol kaplamaların tasarım ve yapımındaki ana hedeflerden biri, optimum koşullarda stabilite ve durabilite açısından en iyi performans1 elde etmektir (Ameri vd., 2018). Sicaklık, hava ve su gibi çevresel faktörler bitümlü sıcak karışımların dayanıklılığı üzerinde önemli bir etkiye sahiptir (Şengöz ve Görkem, 2009). Agrega ve bağlayıcı içerisinde nemin bulunması, bitümlü sıcak karışımların adezif özelliklerini azaltmaktadır (Görkem, 2014).

Bitümlü sıcak karışımların, suya bağlı bozulmalara karşı performansını artırmak için kullanılan en yaygın yöntemler; malzemelerin değiştirilmesi, karışım tasarımında farklılıklara gidilmesi ve soyulma önleyici katk1 maddeleri kullanmaktır (Epps vd., 2003). Soyulma önleyici katkı maddelerinin kullanımı, bitümlü sıcak karışımdaki nem direncini arttırmanın genel ve optimum yoludur. Soyulma önleyici katk1 maddelerinin kullanım yöntemleri iki kategoriye ayrılmaktadır. Bunlardan biri doğrudan bitüme eklenerek, diğeri ise agrega gradasyonuna eklenerek kullanılan yöntemlerdir (Hamedi ve Tahami, 2018).

\section{Materyal ve Yöntem}

$\mathrm{Bu}$ çalışmada, karışımdaki agrega gradasyonunun tamamının depolama alanlarına dökülen kalsit bazlı mermer atığının oluşturduğu bitümlü karışımlarda yeniden kullanımının geleneksel kalker agregası ile hazırlanan bitümlü karışımlara ait performans kiyaslamaları yapılması hedeflenmiştir. Bahsedilenlerin yanı sıra, kalsit bazlı mermer atıkları ile hazırlanan bitümlü karışımların suya bağlı bozulmalara karşı dirençleri de kalker agregası içeren örneklerle karşılaştırılmıştır. Buradaki ana düşünce, gradasyonunun tamamı atık mermerden oluşan bitümlü karışımların performans değerlendirilmesinin yapılması ve esnek üstyapılarda yeniden kullanımı ile depolama sahalarında ortaya çıkan çevresel kirliliği minimize etmektir. $\mathrm{Bu}$ amaç ile çalışma kapsamında, Marshall Karışım Tasarımı yöntemi, bitümlü sıcak karışımlar (BSK) için optimum 
bitüm içeriğini belirlemek amacıyla kullanılmıştır. Laboratuvarda koşullarında dönel viskozite deneyi ile belirlenen karıştırma ve sıkıştırma sıcaklıklarında Marshall numuneleri hazırlanmış olup, bu numunelere Marshall Stabilite ve Akma Deneyi uygulanmıştır. İki farklı tip agrega (kalker agregası ve kalsit bazlı mermer atığı) ile hazırlanan bitümlü karışımların suya bağlı bozulmalara karşı direnci B100/150 penetrasyon sınıfına ait bitüm kullanılarak değerlendirilmiştir. B100/150 penetrasyon sinıfina ait bitüm üzerine geleneksel bitüm testleri uygulanmış ve agregaların özellikleri (kalker ve kalsit bazlı mermer atığı) belirlenmiştir. Bu çalışmada, farklı agrega türleri içeren bitümlü sıcak karışımların suya bağlı bozulma özellikleri incelenmiştir. $\mathrm{Bu}$ amaçla, karışımların suya bağlı bozulmalar üzerindeki performansının değerlendirilmesinde kalker ve atık mermer agregası ile hazırlanan numunelere soyulma önleyici katkı maddesi olarak sönmüş kireç ilavesi yapılmıştır. Numunelerin suya bağlı bozulma özellikleri, Modifiye Lottman Testi (AASHTO T 283) ile değerlendirilmiştir.

B100/150 penetrasyon sınıfina ait saf bitüm, Türkiye Petrol Rafinerileri Anonim Şirketi İzmir Rafinerisi'nden temin edilmiştir. Saf bitümün özelliklerini belirlemek amaciyla geleneksel bitüm deneyleri yapılmıştır. Deneysel çalışmaların sonuçları Tablo 1' de verilmiştir.

Tablo 1. B100/150 saf bitümün özellikleri

\begin{tabular}{lccc}
\hline Test & Şartname & Sonuçlar & Şartname Limitleri \\
\hline Penetrasyon Deneyi $\left(25^{\circ} \mathrm{C} ; 0.1 \mathrm{~mm}\right)$ & TS EN 1426 & 105 & $100-150$ \\
\hline Yumuşama Noktası $\left({ }^{\circ} \mathrm{C}\right)$ & TS EN 1427 & 40 & $39-47$ \\
\hline Viskozite $\left(135^{\circ} \mathrm{C} ; \mathrm{mPa} . \mathrm{s}\right)$ & ASTM D4402 & 297.5 & 175 (min.) \\
\hline Dönel İnce Film Halinde Isıtma Deneyi $\left(163^{\circ} \mathrm{C} ; 85 \mathrm{dk}.\right)$ & TS EN 12607 & & 0.09 \\
\hline Kütle Değişimi $(\%)$ & & 54 & 43 (maks.) \\
\hline Kalıcı Penetrasyon $(\%)$ & TS EN 1426 $)$ \\
\hline $\begin{array}{l}\text { Dönel İnce Film Halinde Isıtma Deneyi sonrası Penetrasyon Deneyi } \\
\left(25^{\circ} \mathrm{C} ; \text { O.1mm) }\right.\end{array}$ & TS EN 1426 & 57 & \\
\hline $\begin{array}{l}\text { Dönel İnce Film Halinde Isıtma Deneyi sonrası Yumuşama Noktası } \\
\text { Deneyi }\left({ }^{\circ} \mathrm{C}\right)\end{array}$ & TS EN 1427 & 51 & 41 (min.) \\
\hline
\end{tabular}

Bitümlü karışım örnekleri iki farklı tip agrega (Kalker ve Kalsit bazlı Mermer Atığı) kullanılarak elde edilmiştir. Kalker agregaları Muğla ilinde yer alan Kavaklıdere taş ocağından, kalsit bazlı mermer atığı agregaları ise yine Muğla ilinde yer alan Yatağan taş ocağından elde edilmiştir. Çalışma kapsamında kullanılan agrega çeşitlerine ait özelliklerin saptanabilmesi amaciyla geleneksel agrega deneyleri yapılmıştır. Gradasyon değerleri, Karayolları Teknik Şartnamesi (KTŞ) Aşınma Tip-1 esaslarına uygun olarak seçilerek kalker ve kalsit bazlı mermer atığ agregasının özellikleri Tablo 2 ve Tablo 3 ' te sırasıyla gösterilmiştir.

Tablo 2. Kalker agregasına ait özellikler

\begin{tabular}{|c|c|c|c|}
\hline Test & Şartname & Sonuçlar & Şartname Limitleri \\
\hline Elek No & ASTM C 136 & & \\
\hline $3 / 4 "$ & & 100 & 100 \\
\hline $1 / 2 "$ & & 92 & $83-100$ \\
\hline $3 / 8 ”$ & & 80 & $70-90$ \\
\hline No 4 & & 47.3 & $40-55$ \\
\hline No 10 & & 33 & $25-38$ \\
\hline No 40 & & 13 & $10-20$ \\
\hline No 80 & & 9 & $6-15$ \\
\hline No 200 & & 5.3 & $4-10$ \\
\hline Kaba Agrega Özgül Ă̆ırlığı & ASTM C 127 & & \\
\hline Hacim & & 2.645 & - \\
\hline Kuru Yüzey Doygun & & 2.666 & - \\
\hline Zahiri & & 2.713 & - \\
\hline İnce Agrega Özgül Ağırlığı & ASTM C 128 & & \\
\hline Hacim & & 2.643 & - \\
\hline Kuru Yüzey Doygun & & 2.672 & - \\
\hline Zahiri & & 2.722 & - \\
\hline Filler Özgül Ağırlığı & & 2.686 & - \\
\hline Los Angeles Aşınmması (\%) & TS EN 1097-2 & 27.4 & Maks. 27 \\
\hline Yassılık İndeksi (\%) & BS 812 & 5 & Maks. 10 \\
\hline Hava Tesirlerine Karşı Dayanıklılık $\left(\mathrm{MgSO}_{4}\right)(\%)$ & TS EN 1367-2 & 4.154 & Maks. 16 \\
\hline
\end{tabular}


Tablo 3. Kalsit bazlı mermer atı̆̆

\begin{tabular}{|c|c|c|c|}
\hline Test & Şartname & Sonuçlar & Şartname Limitleri \\
\hline Elek No & ASTM C 136 & & \\
\hline $3 / 4 "$ & & 100 & 100 \\
\hline $1 / 2 "$ & & 92 & $83-100$ \\
\hline $3 / 8 "$ & & 80 & $70-90$ \\
\hline No 4 & & 47.3 & $40-55$ \\
\hline No 10 & & 33 & $25-38$ \\
\hline No 40 & & 13 & $10-20$ \\
\hline No 80 & & 9 & $6-15$ \\
\hline No 200 & & 5.3 & $4-10$ \\
\hline Kaba Agrega Özgül Ağırlığ & ASTM C 127 & & \\
\hline Hacim & & 2.679 & - \\
\hline Kuru Yüzey Doygun & & 2.693 & - \\
\hline Zahiri & & 2.716 & - \\
\hline İnce Agrega Özgül Ağırlı̆ğ & ASTM C 128 & & \\
\hline Hacim & & 2.636 & - \\
\hline Kuru Yüzey Doygun & & 2.669 & - \\
\hline Zahiri & & 2.719 & - \\
\hline Filler Özgül Ağırlığı & & 2.706 & - \\
\hline Los Angeles Aşınması (\%) & TS EN 1097-2 & 25 & Maks. 27 \\
\hline Yassılık İndeksi (\%) & BS 812 & 3 & Maks. 10 \\
\hline Hava Tesirlerine Karşı Dayanıklılık $\left(\mathrm{MgSO}_{4}\right)(\%)$ & TS EN 1367-2 & 0.7 & Maks. 16 \\
\hline
\end{tabular}

Deneysel çalışmalar kapsamında kullanılan ve yüksek oranda kalsiyum hidroksit $\left(\mathrm{Ca}(\mathrm{OH})_{2}\right)$ içeren sönmüş kireç katkısı, Muğla Kireç Sanayi
Anonim Şirketi'nden temin edilmiştir. Kullanılan, sönmüş kireç katkısına ait özellikler Tablo 4'te verilmiştir.

Tablo 4. Sönmüş kireç katkısına ait özellikler

\begin{tabular}{|c|c|c|c|c|c|}
\hline \multicolumn{3}{|c|}{ Analiz sonrası Bileşenler } & \multicolumn{3}{|c|}{ Hesaplama sonrası Bileşenler } \\
\hline Adı & Formülü & $\%$ & Adı & Formülü & $\%$ \\
\hline Silisyumdikoksit & $\mathrm{SiO}_{2}$ & 0.40 & Kalsiyumkarbonat & $\mathrm{CaCO}_{3}$ & 3.95 \\
\hline Demiroksit & $\mathrm{Fe}_{2} \mathrm{O}_{3}+$ & 0.12 & Kalsiyumhidroksit & $\mathrm{Ca}(\mathrm{OH})_{2}$ & 95.03 \\
\hline Alüminyumoksit & $\mathrm{Al}_{2} \mathrm{O}_{3}$ & 0.10 & & & \\
\hline Kalsiyumoksit & $\mathrm{CaO}$ & - & Magnezyumkarbonat & $\mathrm{MgCO}_{3}$ & - \\
\hline Magnezyumoksit & $\mathrm{MgO}$ & - & Magnezyumhidroksit & $\mathrm{Mg}(\mathrm{OH})_{2}$ & - \\
\hline Sülfür(III)oksit & $\mathrm{SO}_{3}$ & - & Kalsiyumsülfat & $\mathrm{CaSO}_{4}$ & - \\
\hline
\end{tabular}

$\mathrm{Bu}$ çalışmada kullanılan malzemelerin özelliklerinin belirlenerek, örneklerin hazırlanmasından sonra sıkıştırılmış numuneler üzerinde Marshall Stabilite ve Akma ile Modifiye Lottman (AASHTO T283) deneyleri uygulanmiştır.

Bitümlü sıcak karışımların laboratuvar koşullarında Marshall karışım tasarımı yapılırken, "Marshall Aletini Kullanarak Bitümlü Karışımların Plastik Akmaya Karşı Direnci İçin Standart Deney Yöntemi (ASTM D-1559)" kullanılmaktadır (Önal ve Kahramangil, 1993). $\mathrm{Bu}$ deney yönteminde, 1150 gram olarak hazırlanan agrega numunelerine ağırlıklarınca \%3.5-6.0 oran aralığında (her defada bitüm içeriği
$\% 0.5$ arttırılmak suretiyle) bitüm eklenerek mikserde karıştırılmaktadır. Her bir bitüm içeriği için üç adet numune hazırlanarak 18 numune üzerinde deneysel çalışmalar uygulanmıştır. Bitüm ve agregalar belirlenen karışım sicaklıklarında 1sitıldıktan sonra homojen olacak şekilde karıştırılmıştır. Marshall kalıplarına yerleştirilen numunelerin, her iki yüzeyine de Karayolları Teknik Şartnamesinde (KTŞ) belirtildiği gibi (Aşınma Tabakası Tip-1) 75'er darbe uygulanarak sıkıştırma işlemi gerçekleştirilmiştir (KGM, 2013). Numuneler, dayanım ve akma değerlerinin belirlenmesi amaciyla Marshall deney cihazına yerleştirilmeden önce $60^{\circ} \mathrm{C}$ sicaklığındaki su banyosunda 30-40 dakika bekletilmiştir. $\mathrm{Bu}$ süre 
sonunda numuneler su banyosundan çıkarılarak Marshall deney cihazına yerleştirilerek cihaz çalıştırılmıştır. Cihazın yükleme hızı 50.8 $\mathrm{mm} /$ dak. Olmasına dikkat edilmiştir. Deney, cihaz ekranındaki stabilite ve akma değerleri sabit hale gelene kadar devam ettirilmiştir. Tüm bu işlemlerin 30 saniyelik süre zarfinda özenle yapılması gerekmektedir. Deney sonunda stabilite ve akma okumaları yapilarak veriler kaydedilmiştir.

Sıkıştırılmış bitümlü karışımların sudan kaynaklanan bozulmalara karşı dirençlerinin saptanması için uygulanan deneyde (AASHTO T283, TS EN 12697-12), laboratuvarda hazırlanan sıkıştırılmış bitümlü karışımların hızlandırılmış su etkileri nedeni ile oluşan çap düzlemindeki indirekt çekme mukavemeti (ITS) ölçümünü ve bu deney için numune hazırlanmasını kapsamaktadır. B100/150 saf bitüm kullanılarak hazırlanan bitümlü sıcak karışımlar alüminyum kap içine konularak 2 saat oda sicaklığında soğutulmuşlardır. Sonra karışımlar kür edilmek üzere 16 saat süre ile $60^{\circ} \mathrm{C}^{\prime}$ lik etüvde bekletilmişlerdir. Kür işleminden sonra, $135^{\circ} \mathrm{C}^{\prime}$ lik etüvde 2 saat bekletilmiş karışımlar, $\% 7 \pm 1.0$ hava boşluğunda sıkıştırılmışlardır. B100/150 optimum bitüm içeriği belli olan miktarlara ait, üçer adet numune hazırlanmıştır. Diğer grup numuneler ise metal silindirik piknometre içine konulduktan sonra içine $25^{\circ} \mathrm{C}$ 'de saf su ilave edilerek numuneye su absorbe işlemi uygulanmıştır. İçinde numune olan plastik torba, 16 saat süre ile $-18{ }^{\circ} \mathrm{C}^{\prime}$ lik dondurucu içinde bekletildikten sonra, 24 saat süreyle $60{ }^{\circ} \mathrm{C}$ 'lik su banyosuna konulmuştur. $\mathrm{Bu}$ işlemden sonra, numuneler 2 saat süre ile $25^{\circ} \mathrm{C}$ 'ye ayarlanmış su banyosunda bekletilmişlerdir. Kuru ve yukarıdaki şekilde koşullandırılmış numunelerin ITS değerleri saptanmıştır. Numunelerin suya bağlı bozulmalarını saptamak için, koşullandırılmış numunelerin ITS değerlerinin kuru numunelerinkine oranı bulunmuştur.

\section{Bulgular ve Tartışma}

B100/150 penetrasyon sınıfına ait bitüm ile kalker agregasının, farklı oranlarda kullanılan sönmüş kireç katkısı ile karışım özellikleri araştırılmış ve buna bağlı sonuçlar verilmiştir. Hacimsel özellikler özgül ağırlık, hava boşluğu, asfaltla dolu boşluk (VFA), mineral agregalar arası boşluk (VMA), Marshall Stabilite ve Akma ile elde edilen sonuçlar farklı bitüm içeriği için grafiksel olarak değerlendirilmiştir. Şekil 1-6'da yer verilen bu grafiklerden maksimum Stabilite, maksimum Özgül Ağırlık, \%4 Hava Boşluğu değerine karşıllık gelen bitüm içeriği ve KTŞ'de yer verildiği gibi \%60-75 VFA aralığına denk gelen değerlerin aritmetik ortalaması alınarak optimum bitüm içeriği belirlenmiştir. Elde edilen sonuçlar, sırasıyla $\% 0, \% 1.0, \% 1.5$ ve $\% 2.0$ sönmüş kireç içeriği ile optimum bitüm içeriğinin sirasiyla $\% 4.37, \% 4.57, \quad \% 4.62$ ve $\% 4.67$ olduğunu göstermektedir (Şekil 1-6).

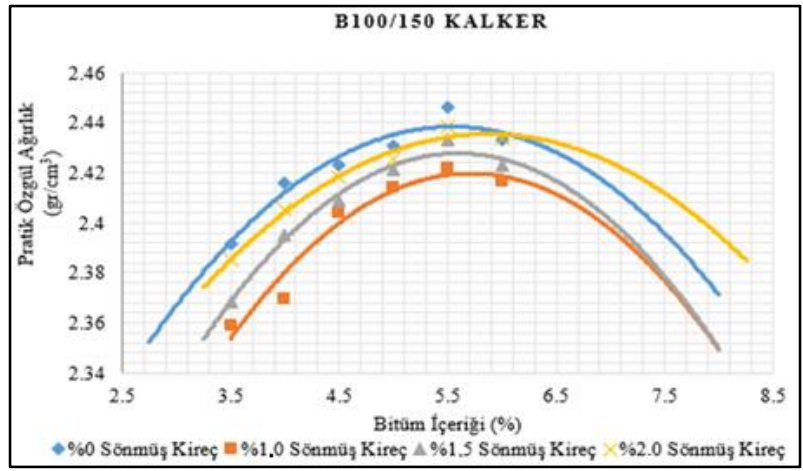

Şekil 1. Farklı oranlardaki sönmüş kireç katk1lı örneklere ait pratik özgül ağırlık-bitüm içeriği sonuçları

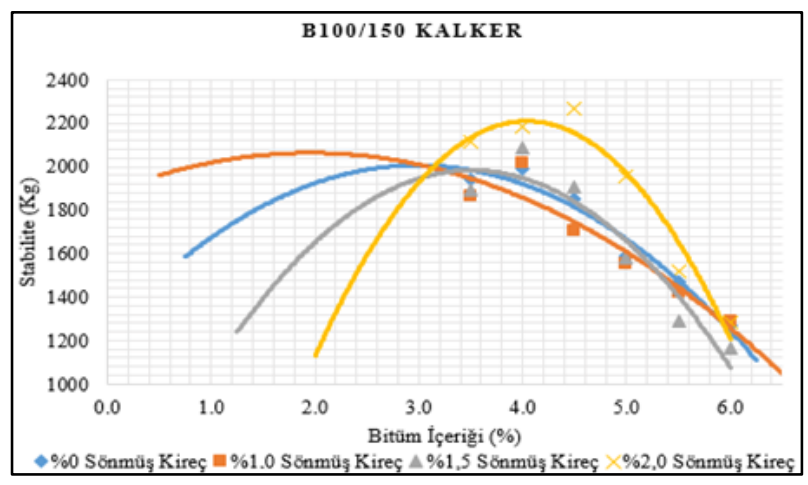

Şekil 2. Farklı oranlardaki sönmüş kireç katkılı örneklere ait stabilite- bitüm içeriği sonuçları

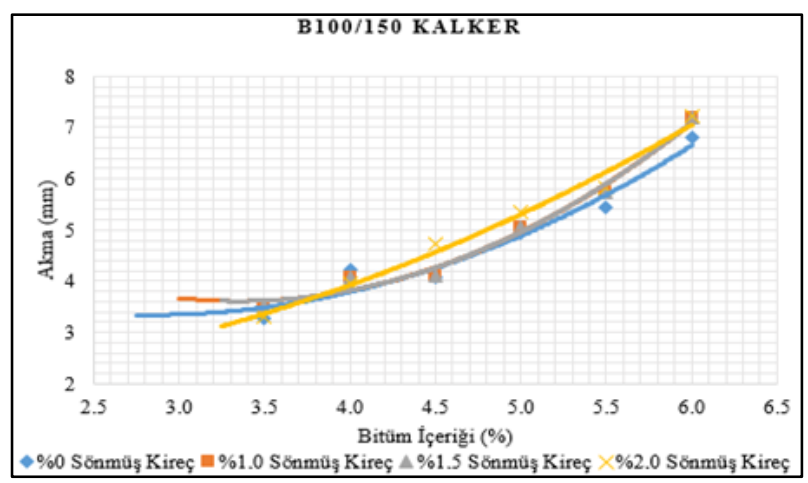

Şekil 3. Farklı oranlardaki sönmüş kireç katkılı örneklere ait akma- bitüm içeriği sonuçları 


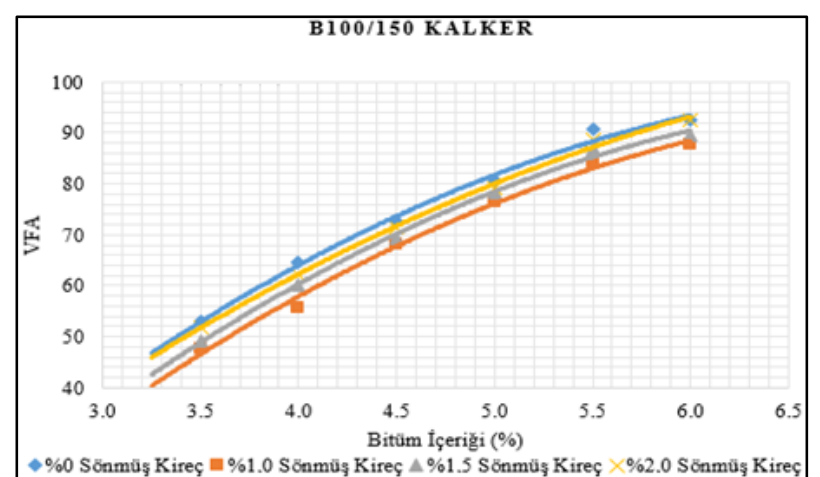

Şekil 4. Farklı oranlardaki sönmüs kireç katkılı örneklere ait VFA-bitüm içeriği sonuçları

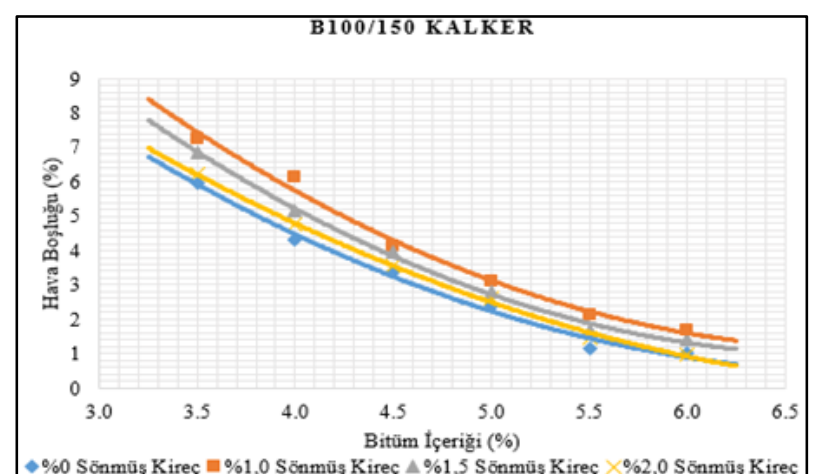

Şekil 5. Farklı oranlardaki sönmüş kireç katkılı örneklere ait hava boşluğu-bitüm içeriği sonuçları

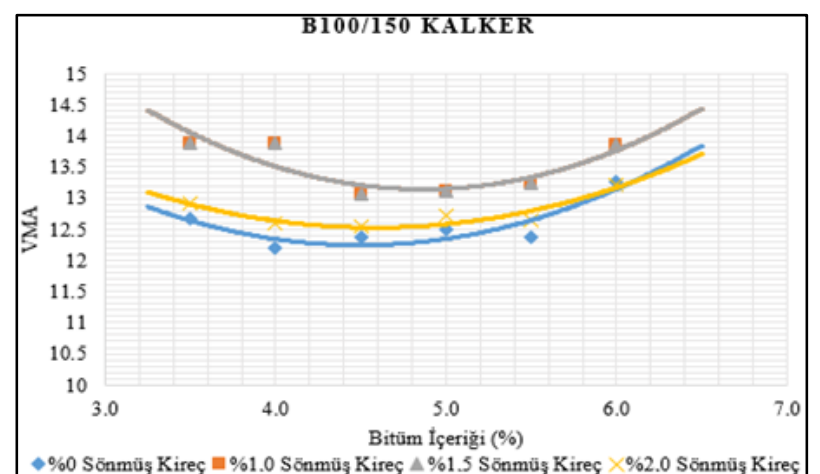

Şekil 6. Farklı oranlardaki sönmüş kireç katkılı örneklere ait VMA-bitüm içeriği sonuçları

B100/150 penetrasyon sınıfına ait bitüm ile kalsit bazlı mermer atığ 1 agregasının, farklı oranlarda kullanılan sönmüş kireç katkısı ile karışım özellikleri araștırılmış, sonuçlar verilmiştir. Hacimsel özellikler özgül ağırlık, hava boşluğu, VFA, VMA, Marshall Stabilite ve Akma ile elde edilen sonuçlar farklı bitüm içeriği için grafiksel olarak değerlendirilmiştir. Grafiklerden maksimum Stabilite, maksimum Özgül Ağırlık, \%4 Hava Boşluğu değerine karşılık gelen bitüm içeriği ve KTŞ'de yer verildiği gibi \%60-75 VFA aralığına denk gelen değerlerin aritmetik ortalaması alınarak optimum bitüm içeriği belirlenmiştir. Elde edilen sonuçlar, \%0, \%1.0, $\% 1.5$ ve $\% 2.0$ sönmüş kireç içeriği ile optimum bitüm içeriğinin sırasıyla $\% 4.22, \% 4.25, \% 4.30$ ve $\% 4.35$ olduğunu göstermektedir (Şekil 7-12).

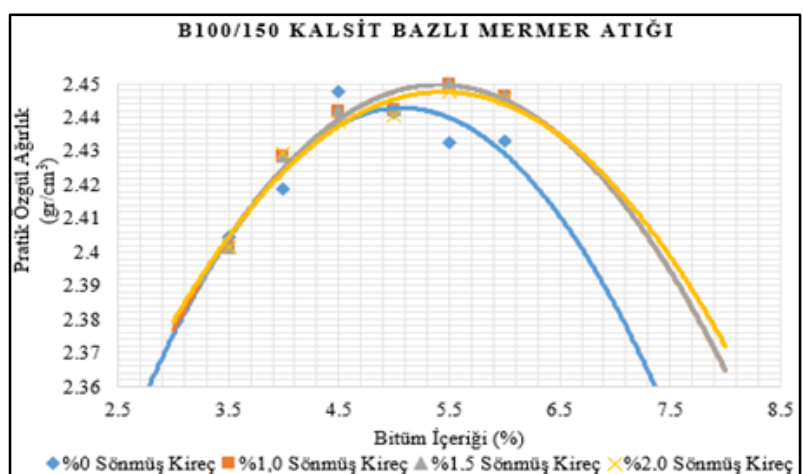

Şekil 7. Farklı oranlardaki sönmüş kireç katkılı örneklere ait pratik özgül ağırlık-bitüm içeriği sonuçları

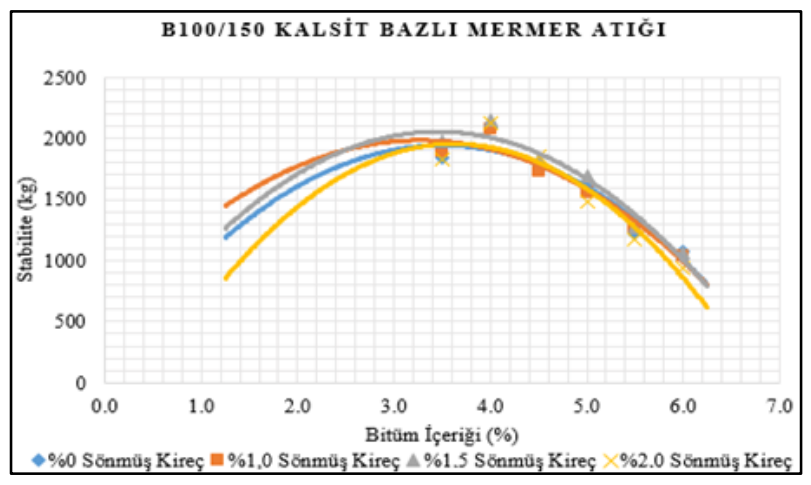

Şekil 8. Farklı oranlardaki sönmüş kireç katkılı örneklere ait stabilite-bitüm içeriği sonuçları

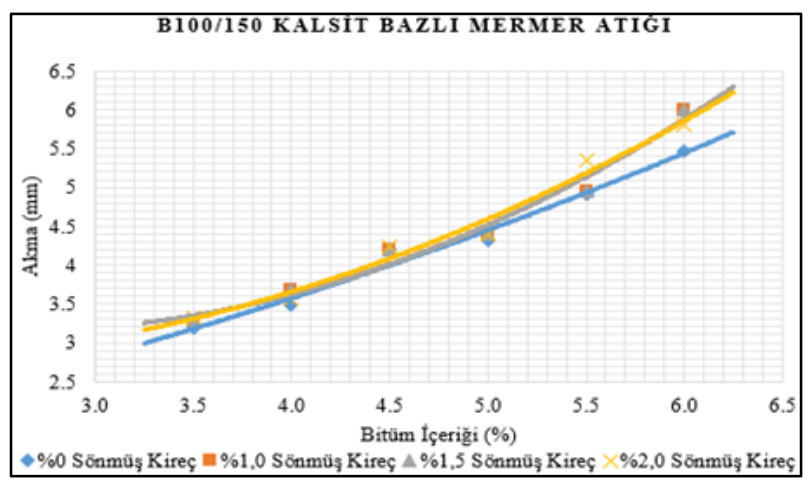

Şekil 9. Farklı oranlardaki sönmüş kireç katkılı örneklere ait akma-bitüm içeriği sonuçları

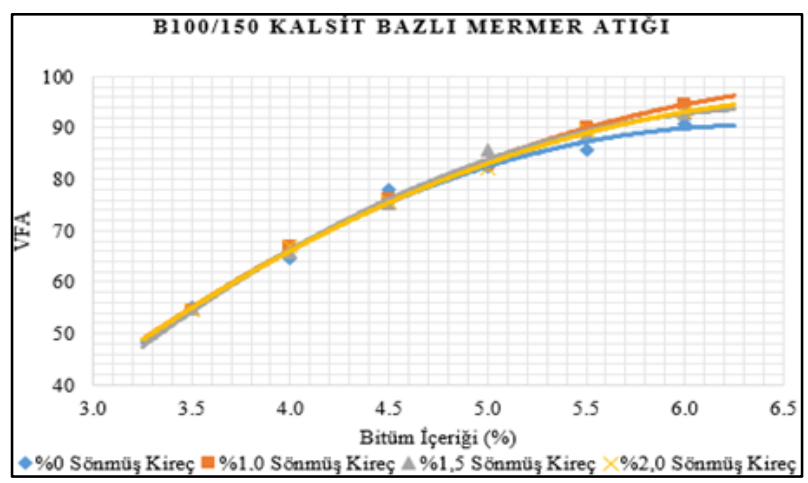

Şekil 10. Farklı oranlardaki sönmüş kireç katkılı örneklere ait VFA-bitüm içeriği sonuçları 


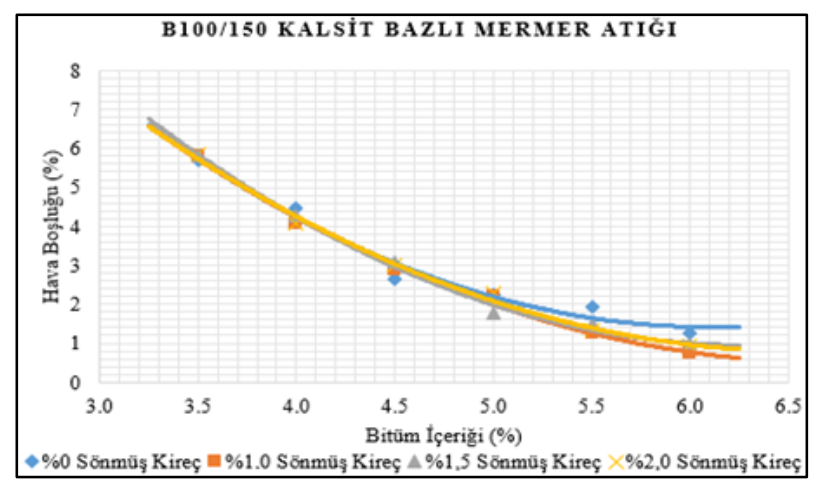

Şekil 11. Farklı oranlardaki sönmüş kireç katkılı örneklere ait Hava Boşluğu-bitüm içeriği sonuçları

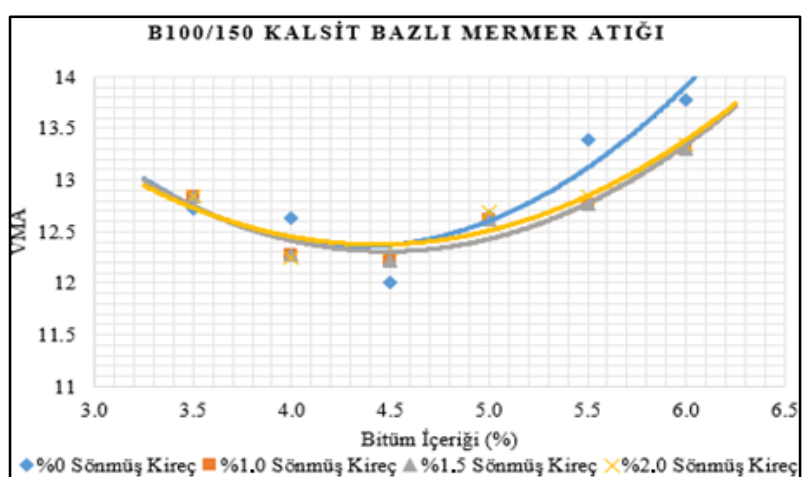

Şekil 12. Farklı oranlardaki sönmüş kireç katk1lı örneklere ait VMA-bitüm içeriği sonuçları

Tablo 5. Farklı oranlardaki sönmüş kireç katkısına ait optimum bitüm içerikleri

\begin{tabular}{|c|c|c|c|c|}
\hline Bitüm & Agrega & Katkı & Katkı İçeriği (\%) & Optimum Bitüm İçerikleri \\
\hline \multirow{8}{*}{ B100/150 } & \multirow{4}{*}{ Kalker } & \multirow{8}{*}{ Sönmüş Kireç } & 0 & 4.37 \\
\hline & & & 1.0 & 4.57 \\
\hline & & & 1.5 & 4.62 \\
\hline & & & 2.0 & 4.67 \\
\hline & \multirow{4}{*}{ Kalsit Bazlı Mermer Atığı } & & 0 & 4.22 \\
\hline & & & 1.0 & 4.25 \\
\hline & & & 1.5 & 4.30 \\
\hline & & & 2.0 & 4.35 \\
\hline
\end{tabular}

Farklı oranlardaki sönmüş kireç katkısı için optimum bitüm içerikleri Tablo 5'de verilmiştir. Genel bir değerlendirme yapılacak olursa, B100/150 sinıfina ait bitümlü malzeme ile hazırlanan karışım örnekleri için karışıma sönmüş kireç ilavesi ile birlikte optimum bitüm içeriklerinde $(\mathrm{OBC})$ de artış olduğu gözlemlenmektedir.
Farklı oranlarda sönmüş kireç katkısı için optimum bitüm içerikleri tespit edildikten sonra, Marshall stabilite ve akma parametreleri üzerine numunelere sönmüş kireç ilavesinin etkisi belirlenmiştir. Farklı oranlardaki sönmüş kireç katk1sı ile uygulanan Marshall stabilite ve akma deneyine ait sonuçlar Tablo 6'de verilmiştir.

Tablo 6. Farklı oranlardaki Sönmüş Kireç katkısı ile hazırlanan Marshall stabilite ve akma deneyi sonuçları

\begin{tabular}{|c|c|c|c|c|c|}
\hline Bitüm & Agrega & Katkı & Katkı İçeriği (\%) & Düzeltilmiş Stabilite $(\mathrm{kg} f)$ & $\operatorname{Akma}(\mathrm{mm})$ \\
\hline \multirow{8}{*}{$\mathrm{B} 100 / 150$} & \multirow{4}{*}{ Kalker } & \multirow{8}{*}{ Sönmüş Kireç } & 0 & 1472 & 4.2 \\
\hline & & & 1.0 & 1521 & 4.5 \\
\hline & & & 1.5 & 1623 & 4.7 \\
\hline & & & 2.0 & 1843 & 4.8 \\
\hline & \multirow{4}{*}{ Kalsit Bazlı Mermer Atığı } & & 0 & 1951 & 3.6 \\
\hline & & & 1.0 & 2150 & 4.2 \\
\hline & & & 1.5 & 2180 & 3.4 \\
\hline & & & 2.0 & 2223 & 3.8 \\
\hline
\end{tabular}

Tablo 6'dan da anlaşılacağı üzere, farklı oranlardaki sönmüş kireç katkısı ile hazırlanan bitümlü karışım örnekleri, saf bitüm içeren örnekler ile karşılaştırıldığında stabilite değerlerinin arttığ1 görülmektedir. Farklı oranlardaki sönmüş kireç katk1 içerikleri için, Marshall stabilite değerleri KTŞ'ye uygun olduğu belirlenmiştir. Maksimum stabilite değerlerine \%2.0 sönmüş kireç içeriklerinde ulaşılmıştır. Tablo 6 akma değerleri bakımından 
incelendiğinde, farklı oranlardaki sönmüş kireç katkısı ile hazırlanan kalker agregasına ait değerlerin katkı içeriği arttıkça az miktarda da olsa arttığ1 görülmektedir. Kalsit agregasının ise $\% 1.0$ sönmüş kireç katkı içeriği için şartname üst sınırı olan $4.0 \mathrm{~mm}$ seviyesini bir miktar aştığ görülmektedir.
Çalışmada gerek kalker gerekse kalsit bazlı mermer atıkları ile hazırlanan bitümlü karışımların suya bağlı bozulmalara karşı direnci üzerine de değerlendirmeler yapılmış, Şekil 13 'de çalışma kapsamında kullanılan farklı oranlardaki sönmüş kireç katkısı için belirlenen optimum bitüm içerikleriyle hazırlanan bitümlü sıcak karışım örneklerine ait ITS ve çekme dayanım oranı (TSR) sonuçları verilmiştir.

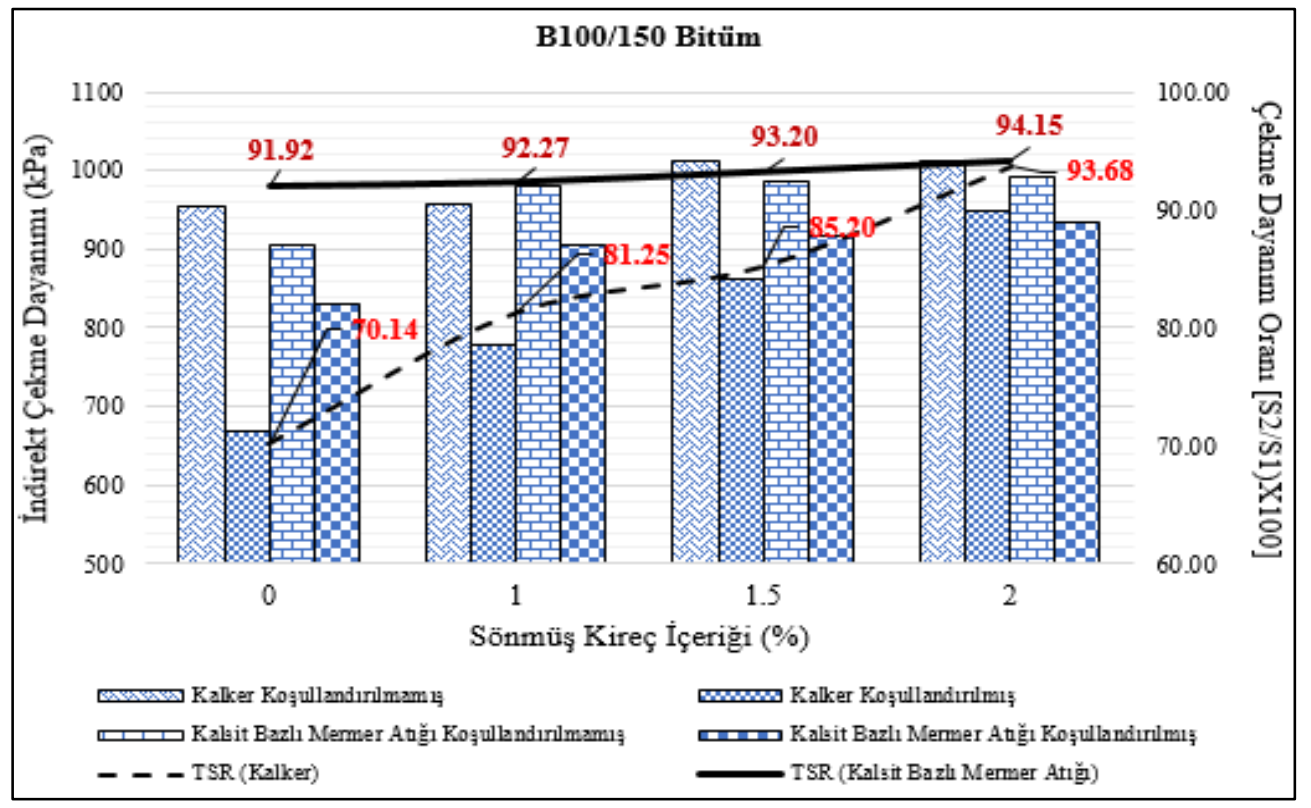

Şekil 13. İndirekt çekme gerilmesi ve çekme dayanım oranına ait deney sonuçları

Şekil 13 incelendiğinde, gerek kalsit gerekse kalker agregası ile hazırlanan bitümlü karışım örnekleri için farklı oranlardaki sönmüş kireç içerikleri İndirekt Çekme Dayanım değerlerinde, saf bitüm ile hazırlanan örneklere göre artış sağladığı belirlenmiştir. Koşullandırılmış kalker agregası ile hazırlanan bitümlü karışım örnekleri için, sönmüş kireç içeriği arttıkça, ITS değerlerinin de arttığ 1 görülmüştür. \%1.5 sönmüş kireç içeriğinden sonraki içerikte hazırlanan örneklerde ise ITS değerlerinde önemli bir değişiklik gözlemlenmemiştir. Kalker agregası ile hazırlanan "koşullandırılmış" bitümlü karışım örneklerinde ise bitüme sönmüş kireç ilavesi ile ITS değerlerinde önemli ölçüde artış tespit edilmiştir. Elde edilenlere göre, koşullandırılmış numuneler için bitüme sönmüş kireç ilavesi, karışımın çekme dayanımını direkt olarak arttırmaktadır. Kalsit bazlı mermer atığ ile hazırlanan bitümlü karışım numuneleri Şekil 13 'teki değerler dikkate alınarak incelendiğinde, koşullandırılmamış örnekler için sönmüş kireç katk1 içeriği arttıkça ITS değerlerinde de artış yaşandığı belirlenmiştir. Aynı çeşit agrega atığı ile hazırlanarak koşullandırılmış bitümlü karışım örneklerine sönmüş kireç katkısının eklenmesi ile birlikte ITS değerlerinde \%1.0 katk1 içeriğinden itibaren doğrusal (lineer) sayılabilecek bir artış yaşanmıştır. Yine Şekil 13 incelendiğinde, gerek kalker agregası gerekse kalsit bazlı mermer atığı ile hazırlanan bitümlü karışımlar için sönmüș kireç katkısı içeriği arttıkça TSR değerlerinin de arttığ 1 görülmektedir. Bahsi geçen bu artış, kalker agregası ile hazırlanan bitümlü karışım örnekleri için çok daha belirginken, kalsit bazlı mermer atığ 1 ile hazırlanan örnekler için daha az bir oran olarak gerçekleşmiştir. Şekil 13 karışımların sudan kaynaklanan bozulmalara karşı dirençlerini ifade eden TSR bakımından incelendiğinde, sönmüş kireç katkı içeriklerine ait TSR oranının saf bitüme ait TSR oranından yüksek değerler aldığ1 görülmektedir. Her iki grup agrega ile hazırlanan bitümlü karışımlara ait TSR sonuçları birlikte değerlendirildiğinde, karıșıma soyulma önleyici katk1 olarak sönmüş kireç ilavesinin kalker ile hazırlanan bitüm karışımlarda neme karşı hassasiyet verilerini kalsit bazlı mermer atığ örneklerine göre çok daha önemli ölçüde 
etkilediği görülmektedir. Bunun nedeni olarak, sönmüş kirecin karboksilik asitlerle etkileşime girmesi ile agrega yüzeyinde çözünmeyen tuzlar oluşturmak suretiyle bitüm ile agrega arasındaki adezyonu arttırması olduğu söylenebilir (Petersen vd.,1987; Hicks, 1991). Bununla birlikte, en yüksek TSR değerine, \%2.0 sönmüş kireç içeriğinde ulaşıldığı tespit edilmiştir.

\section{Sonuç}

Çalı̧̧mada, kullanılan B100/150 sinıfina ait bitümlü malzemeye ilişkin geleneksel bitüm deneyleri yapılmıştır. Buna göre, elde edilen sonuçların KTŞ'de yer alan limitler içerisinde kaldığı belirlenmiştir. Bitümlü bağlayıcıların kısa süreli yaşlanma etkilerinin belirlenmesinde en s1k kullanılan yöntem olan Dönel İnce Film Halinde Isıtma Deneyi (RTFOT) uygulanmıştır. Yaşlandırma işleminden sonra bitümlü bağlayıcıların yumuşama noktası değerlerinin $\operatorname{artt1ğ} 1$, penetrasyon verilerinin ise azaldığ 1 belirlenmiştir. Burada meydana gelen kütle kaybı, bitümün sertleşmesine neden olmakla birlikte, bitümlü sıcak karışımların durabilitesini olumsuz yönde etkilemektedir.

Uygulanan Marshall stabilite ve akma deneylerinden yola çıkarak, karışıma farklı oranlardaki sönmüş kireç ilavesinin asfalt betonu örneklerine ait stabilite değerlerinde olumlu yönde bir etki yarattığı anlaşılmıştır. Ayrıca, deformasyon özelliklerini yansitan parametrelerden biri olan akma deneyi sonuçlarına göre, kalker agregası ile hazırlanan bitümlü karışımlara artan oranda sönmüş kireç ilavesi ile örneklerin olumsuz etkilendiği, kalsit bazlı mermer agregası ile hazırlanan örneklerin ise şartname limitleri olan 2-4 mm arasında kaldığ belirlenmiştir. Sönmüş kireç içeriği arttıkça Marshall stabilite ve akma değerlerinin de arttığ1 gözlemlenmiştir. Kalsit bazlı mermer atığı ile benzer kimyasal özelliklere sahip sönmüş kirecin yüksek katkı oranları ile kullanımının, karışımda yer alan filler oranını arttırarak bitümlü karışım örneklerinde sertleşmeye neden olduğu ve stabilite değerlerini arttırdı ̆ ${ }_{1}$ anlaşılmaktadır. Benzer bir düşünce ile bitümlü karışımlara artan oranda sönmüş kireç ilavesinin, kaplamanın elastik özellikleri hakkında değerlendirme yapma imkanı tanıyan akma parametresi için de aynı doğrultuda bir sonuç vermesi beklenirken, önceki bölümlerde de bahsedildiği üzere karışıma sönmüş kireç ilavesinin karışımın optimum bitüm içeriğini (OBC) arttırmasından dolayı akma değerlerinde bir azalma görülmemiş, tersine oldukça az miktarda da olsa bir artış yaşanmıştır.
AASHTO T 283 Modifiye Lottman deneyi ile elde edilen veriler 1şığında yapılan suya karşı duyarlılık analizleri, kalsit bazlı mermer atığı agregası ile hazırlanan bitümlü karışımların, kalker agregası ile hazırlanan karışım örneklerine göre neme karşı hassasiyetlerinin daha az olduğunu göstermiştir. \%2.0 sönmüş kireç katk1 içeriği ile hazırlanan bitümlü karışımların sudan kaynaklanan bozulmalara karşı en yüksek değeri verdiği belirlenmiștir. Bu durumun, kalsit bazlı mermer atığı agregasının yüksek orandaki kalsiyum karbonat içeriği sayesinde bazik olduğu ve asfalt bağlayıcının ise asidik yapıda olmasıyla birlikte bir bağ oluşturarak, çekme dayanım oranını arttırdığı düşünülmektedir. Sönmüş kireç katkısının performans ve çevresel faktörler bakımından bitümlü sıcak karışımlara olumlu yönde etkisinin olduğu söylenebilir. Bu çalışma kapsamında agregalar ve bitümlü sıcak karışımlar üzerine yapılan deneyler sonucunda kalsit bazlı mermer atığ1 agregasının şartname değerlerini sağladığı, orta ve düşük hacimli trafik akışına sahip yollarda kalker agregasına alternatif olarak kullanılabileceği düşünülmektedir.

\section{Teşekkür:}

$\mathrm{Bu}$ çalışma Muğla Sitkı Koçman Üniversitesi Bilimsel Araştırma Projeleri Koordinasyon Birimi tarafindan 2017/022 proje numaras1 ile desteklenmiştir. Bilimsel Araştırma Koordinasyon Birimi'ne, deneysel çalışmalarımızda kullanılmak üzere kalsit bazlı mermer agregasını tarafımıza temin eden Ermaş Madencilik San.Tur.Tic.A.Ş.'ye, bitümlü malzeme ve kalker agregasının temini için Karayolları Genel Müdürlüğü 2. Bölge Müdürlüğü 26. Şube Şefliğine desteğinden ötürü teşekkür ederim.

\section{Kaynaklar}

Akbulut, H. ve Gürer, C., 2003. The Environmental Effects of Waste Marble and Possibilities of Utilization and Waste Minimization by Using in the Road Layers. Proceeding of the Fourth National Marble Symposium, 371-378 pp.

Akbulut, H. ve Gürer, C., 2006. Attk Mermerlerin Asfalt Kaplamalarda Agrega Olarak Değerlendirilmesi. İMO Teknik Dergi, 261, 3943-3960.

Ameri, M., Vamegh, M., Naeni, S.F.C. ve Molayem, M., 2018. Moisture Susceptibility Evaluation of Asphalt Mixtures Containin Evonik, Zycoterm and Hydrated Lime. Construction and Building Materials, 165, 958-965. 
Aravind, K. ve Das, A. 2004. Industrial Waste in Highway Construction, Pebbles. 1st issue, Society of Civil Engineers, IIT Kanpur.

Epps, J., Berger, E. ve Anagnos, J., 2003. Treatments, Moisture Sensitivity of Asphalt Pavements-A National Seminar, Transportation Research Board, San Diego, California.

Görkem, İ.Ç., 2014. Orta Sıcaklıktaki Asfalt Karıșımlarının Performanslarının Değerlendirilmesi. Doktora Tezi, Dokuz Eylül Üniversitesi Fen Bilimleri Enstitüsü, İzmir, $177 \mathrm{~s}$.

Hamedi, H. ve Tahami, S.A., 2018. The Effect of Using Anti-Stripping Additives on Moisture Damage of Hot Mix Asphalt. International Journal of Adhesion and Adhesives, 81, 90-97.

Hicks, RG., 1991. NCHRP Synthesis of Highway Practice 175: Moisture Damage in Asphalt Concrete. Washington (DC): Transportation Research Board, National Research Council.
Karasahin, M. ve Terzi, S., 2007. Evaluation of Marble Waste Dust in the Mixture of Asphaltic Concrete, Construction \& Building Materials, 21, 617-620.

Karayolları Genel Müdürlüğü (KGM), 2013. Karayolu Teknik Şartnamesi 2013, KGM Teknik Araştırma Dairesi Başkanlığı Basım Evi, Ankara, 431s.

Önal, A.M. ve Kahramangil, M., 1993. Bitümlü Karışımlar Laboratuvar El Kitabı, KGM Teknik Araştırma Dairesi Başkanlığı Basım Evi, Ankara, 156s.

Petersen, J.C., Plancher, H. ve Harnsbergen, P.M., 1987. Lime Treatment of Asphalt to Reduce Age Hardening and İmprove Flow Properties. In: Proceedings, AAPT, vol. 56.

Şengöz, B. ve Görkem, C., 2009. Predicting Stripping and Moisture İnduced Damage of Asphalt Concrete Prepared with Polymer Modified Bitumen and Hydrated Lime. Construction \& Building Materials, 23 (6), 2227-2236. 